\title{
Why Are They So Afraid of Children's Books? The Subversive Power of Imagination (Part 2)
}

\section{Abstract:}

The second part of the article explores particular examples of subversive books in American, Soviet, and Russian children's literature as well as the revolutionary role of fantasy and innovative literary forms through different periods of the history of the USA, the Soviet Union, and Russia. To show how children's literature was often at odds with particular governments and common opinions, the article uses the examples of the American Left writings for young readers, the 1920s Soviet children's prose and poetry, and contemporary Russian children's books. The article discusses the various attempts of governmental censorship and control over this literature and the ability of writers and publishers to resist the ideological and political pressures.

\section{Key words:}

American literature, censorship, children's and young adult literature, fantasy, Russian literature, social disobedience, Soviet literature, subversiveness

\section{Skąd taki lęk przed książkami dla dzieci? Wywrotowa moc} wyobraźni (część 2)

\section{Abstrakt:}

W drugiej części artykułu zbadano konkretne przykłady wywrotowych książek w amerykańskiej, radzieckiej i rosyjskiej literaturze dziecięcej, a także rewolucyjną rolę fantastyki i innowacyjnych form literackich w różnych okresach historii Stanów Zjednoczonych, Związku Radzieckiego i Rosji. Aby pokazać, w jaki sposób literatura dziecięca często była sprzeczna ze stanowiskami danych rządów i powszechnymi opiniami, w artykule wykorzystano przykłady amerykańskiej lewicowej

* Olga Bukhina - MA, is a translator, writer, and independent scholar. Her research interests include American and Russian children's literature, the images of orphans and death in children's books, and the history of translation of children's literature. Contact: bukhina.olga@gmail.com. 
twórczości dla młodych czytelników, radzieckiej prozy i poezji dziecięcej lat 20. XX wieku oraz współczesnych rosyjskich książek dla dzieci. Artykuł omawia różne próby rządowej cenzury i kontroli nad literaturą dziecięcą oraz zdolność pisarzy i wydawców do przeciwstawiania się presji ideologicznej i politycznej.

\section{Słowa kluczowe:}

literatura amerykańska, cenzura, literatura dziecięca i młodzieżowa, fantastyka, literatura rosyjska, nieposłuszeństwo społeczne, literatura radziecka, subwersywność

Don't trust anyone over 30.

- Jack Weinberg, Free Speech Movement activist

\section{Introduction: Revolutionary Role of Fantasy}

$\mathbf{T}$ he first part of the article contains a general discussion on the psychological roots of creativity, playfulness, and subversiveness in children's literature together with a discussion of Bakhtinian approach to the analysis of children's books that portray fantastic worlds of freedom and fight against oppression. Part 1 also explores the grotesque bodily transformations in children's books and some bodily functions previously unseen in children's literature. Part 2 will talk about the revolutionary role of fantasy using particular examples of American and Russian (Soviet and post-Soviet) children's books. Is fantasy in children's and teens' literature just a fantasy, or does it tell us something very serious about reality? "All fantasy is political, even - perhaps especially - when it thinks it is not" (Bould, Vint, 2012, p. 102). Fantasy, according to Rosemary Jackson (2003), "lies outside the law," and what is even more important, "outside dominant value systems" (p. 4). This connection between the political and the fantastical was obvious for the German/American philosopher and socialist Herbert Marcuse. His understanding of the role of fantasy was based on his reading of Freud's theory. "Marcuse believes that the outlines of a new reality principle are found in the images of phantasy and its aestheticembodiments, and in turn he grounds his high evaluation of phantasy and art in Freud's instinct theory" (Kellner, 1984, p. 174). The power of imagination provides a serious challenge to the established cultural practices. "The rebellion of youth intelligentsia, the right and the truth of imagination" (Marcuse, 1969, p. 30) became a revolutionary force in art in general.

In my opinion, the importance of the revolutionary potential of children's literature in particular cannot be underestimated; we can see such a force throughout the history. A political component was not absent from children's 
literature from its inception; it exists, for example, just as hints in many nursery rhymes. Well-known rhymes London Bridge is Falling Down or Robin the Bobbin, the Big-bellied Ben originally were epigrams mocking the politics of Henry VIII, and later came down to the nursery. Children are natural rebels; the "Mary, Mary, quite contrary" attitude is very familiar to any parent. The anarchic, unruly tendencies of children's literature expressed themselves in rhymes for very small children, and only much later in the $20^{\text {th }}$ and $21^{\text {st }}$ century did they became fully visible in fantasy and dystopian books for kids and teens. Children's fantasy literature as fantasy in general "traces the unsaid and the unseen of culture: that which has been silenced, made invisible, covered over and made 'absent'" (Jackson, 2003, p. 4). The subversive tendencies of children's literature may be expressed not only through the content but also through the form, or rather though the combination of a particular form with an absurdist context that is very popular in children's poetry, both in English (i.e. Edward Lear's limericks or Dr. Seuss's funny poems) and in Russian (in works of the early Soviet OBERIU ${ }^{1}$ poet Daniíl Kharms about whom I will talk later). Anarchy and the absurd in poetry are very attractive to children exactly because it is a combination of a strict poetic form and illogical, but exciting content. The topsy-turvy, upside-down world of fairy tales and books for small children paves the way for the pre-teens and teens literature of social disobedience. There, the fate of the world depends on a child, not on adults, as we have already seen in Part 1 in the discussion of the Harry Potter series. There are also plenty of American dystopian novels, such as Lois Lowry's (1993) The Giver, or Suzanne Collins's (2008-2010) The Hunger Games, with similar ones in England, France, Russia, or other countries. ${ }^{2}$ They convey the message that the problems which cannot be solved by adults are in the mighty hands of a child or a teen. The fantastic mode is very helpful here because it gives the author more freedom to explore the human nature. As Maria Nikolajeva (2010/2012) states:

The fantastic mode allows children's writers to deal with important psychological, ethical, and existential questions in slightly detached manner, which

1 The word OBERIU is an abbreviation of Ob"edinenie Real'nogo Iskusstva, the association for real art, with the last ' $u$ ' added just for fun and an absurdist touch. For various examples of Daniíl Kharms's prose and poetry, see Ostashevsky (2006), Kharms (2009), Mayakovsky, Mandelstam, and Kharms (2017).

2 Just to offer a couple of contemporary examples: How I Live Now by a British-American author Meg Rosoff (2004); Le combat d'hiver [Winter's End] by a French writer Jean-Claude Mourlevat (2006/2009); Zhivye i vzroslye [The Alive and the Adults] by a Russian writer Serger Kuznețov (2011). 
frequently proves more effective with young readers than straightforward realism. For example, the battle of good and evil may be less disturbing, yet more persuasive when described within the imaginary world than in the reader's immediate surroundings. [...] In particular, fantasy may empower a child protagonist in a way so called realistic prose is incapable of doing (p. 42).

The idea of the fantastic world, or as scholars call it, a 'secondary' world of fairy tales, magic realism, fantasy, and science fiction, opens multiple possibilities of breaking the rules and regulation of the so-called 'primary' world. ${ }^{3}$ In children's books, both worlds often exist side by side, sometimes in a form of two narratives, and the book's character moves freely between the 'primary' and the 'secondary' worlds, as do Lewis Carroll's (1865) Alice, Bastian Balthazar of Michael Ende's (1979/1993) The Neverending Story, or Harry Potter of J. K. Rowling (1997-2007). Using this literary device, a lot of children's books effectively talk about a symbolic struggle between the Good and the ultimate Evil, but some works of children's literature may also express a direct political message of a particular group at the particular historical time.

\section{For Young American Comrades}

According to Marcuse's theory, "a new reality principle and values will subvert present repressive-conformist thought and action" (Kellner, 1984, p. 340). Marcuse (1969) believed that "radical political practice involves a cultural subversion" (p. 10), and it will lead to a political rebellion. British and American communist and socialist writers were actively involved in the attempt to subvert the dominant culture by writing for children. Starting in the early $20^{\text {th }}$ century, they were producing politically charged pieces for children of all ages. These pieces cover many different genres, from the 'Socialist Primers' to the school stories, from the narratives of strikes and protests to very untraditional fairy tales, often with new and rich illustrations. Unfortunately, many of these writers were so preoccupied with the direct message of the revolutionary struggle that they lost some of their artistic and creative side. That is one of the reasons why they never reached a broader readership beyond the 'red diaper

3 The functioning of a 'secondary' world in literature is a very well-researched area of literary studies; see, for example, Bowers (2004), Salminen (2009), James and Mendlesohn (2012). But the first and most important is a seminal J. R. R. Tolkien's essay "On Fairy-Stories," written (originally as "Fairy Stories") for presentation at the University of St. Andrews in 1939 and first published in 1947; see Flieger, Anderson (2008). 
babies,' whose parents were members of the United States Communist Party or some sympathisers of the cause. The other reason was, obviously, political. Still, among them there are some true gems deserving a broader recognition. A large corpus of these writings was collected by two American scholars, Julia Mickenberg and Philip Nel (2008), in their anthology, Tales for Little Rebels: A Collection of Radical Children's Literature. The collection covers a significant span of time, basically three quarters of the $20^{\text {th }}$ century. The political range of the authors in the anthology is quite broad; some of them are on the orthodox Marxist-Stalinist side of the spectrum, like M. Boland (1935/2008), probably a British writer. This author's picture alphabet, "ABC for Martin," from Martin's Annual is heavily populated with Marx, 'Bolshies,' Kremlin, Lenin, and Stalin: "K stands for Kremlin, where our Stalin lives; L is the Lead he so ably gives. $\mathrm{M}$ is for Marx whose teachings proves true; $\mathrm{N}$ is the Nemesis long overdue. [...] S stands for Stomachs that wages can't fill; T is for Trials that won't break our will. U stands for Union of 'Soviet's fame'; V was for Victory when our Lenin came" (p. 21). This direct message now, alas, can be seen only as a curious historical artefact.

Many other authors in the collection are more concerned with the specific issues of American union struggle, racial discrimination, portraying Black history, and feminism, and, as a result, are much less dogmatic. The "Organize" part of the anthology is mostly devoted to labour struggle. As the editors of the volume explain, "[i]t is not a coincident that most of the stories in this section came from the 1930s. During that decade, unions grew rapidly and won legal rights in the United States. [...] In this collection, several stories' aims are more subversive than those of major unions in the 1930s"; they "present organizing as a means not just to securing better working conditions but for overthrowing capitalist rulers" (Mickenberg, Nel, 2008, p. 96). That makes these stories still quite relevant. In one of the them, a play $R e$ volt of the Beavers by a Brooklyn native Oscar Saul (1936/2008), the beavers are, naturally, exploited workers with their exiled leader Oakleaf. Two kids, Paul and Mary, are blown by the wind to the beavers' country where the bad Chief and his gang are tough on everyone. In the entire Beaverland, only the Chief and his gang have blue sweaters and skates. The Chief also closed all schools, so another character of the play, a wise beaver called Professor, is out of work. The following discussion about the means of resistance sounds very contemporary. Paul suggests that he will "punch the chief right on the nose... and his whole gang too," and the Professor suggests much more peaceful solution: "Don't start any fights. I'm gonna do something, I'm gonna tell the chief a story... not a plain story... but a story with a moral... and then that'll 
show him how mean he is and then he'll turn into a good chief" (p. 116). In the end, the beavers, Oakleaf, Professor, and the children, are able to organise themselves and to get rid of the Chief and his henchmen. "In their newly liberated Beaverland, each beaver gets enough to eat, along with a sweater and skates" (p. 110).

Another section of the book is a group of texts under an umbrella of fantasy, and it is appropriately entitled "Imagine." Editors quote an art educator Robert J. Saunders (1962) who wrote: "Because of its amorality, the imagination is basically subversive. By that we do not mean it is entirely destructive but that it undermines beliefs and the religious, social, aesthetic, and intellectual structures, built upon these beliefs" (p. 12). The feminist struggle takes a form of a fairy tale. These new tales suggest reverse gender roles when princesses are able to save princes, and not vice versa as in traditional stories. In The Practical Princess by Jay Williams (1969/2008), the princess Bedelia received at birth the gift of common sense and practical thinking; as the result, she is capable of overcoming the dragon, getting rid of an inappropriate and annoying solicitor, freeing herself from captivity, and rescuing the prince. And to marry him, because you are supposed to marry the one you saved. The further destruction of the habitual gender structures is illustrated by probably the most interesting piece in the collection, Lois Gold's (1978/2008) X: A Fabulous Child's Story. Upon the request of some scientists, the family of Jones raises their child as a child X, not a girl and not a boy. This child is a part of a "very important Secret Scientific Xperiment” (p. 234). The story describes the difficult process and final victory of a new approach to gender that is gaining popularity nowadays. At first, there are many problems with friends and relatives of X's family, and especially with other children in school. X wears red and white checked overalls and is equally good in spelling bees, a seven-laps boys' relay race, and baking a seven-layer cake; so, nobody can assign a particular gender role to this child. X has some clear advantages compared to other children. "Other children gave to obey all the silly boy-girl rules, because their parents taught them to. Lucky X - you do not have to stick to the rules at all! All you have to do is be yourself" (p. 239). The main point of this short piece is the revolutionary idea that gender rules (and roles), as well as many other rules, are not especially important because they are arbitrary.

Many children's books are "encouraging children to imaging alternatives to adult institutions and practices. For example, in many of Dr. Seuss's books, children challenge the alleged wisdom of adults" (Mickenberg, Nel, 2008, p. 138). Dr. Seuss (Theodor Seuss Geisel), the author of more than 60 children's books with hundreds of million copies and translations into many languages, 
was able to maintain an uneasy balance between the subversive messages of his writing and its broad acceptance. "Dr. Seuss has taught several generations of children how to read while cheerleading for the anarchic power of imagination" (Handy, 2017, p. xxii). Adults tend not to trust children's imagination. As an annoyed father in one of the Dr. Seuss's (1937/1989) books puts it: "Stop telling such outlandish tales / Stop turning minnows into whales" (p. 1). Similarly, in a story by Lynda Gibson (1934/2008), The Teacup Whale, again from the Tales for Little Rebels collection, a boy finds a tiny whale in a big puddle, and nobody believes him that it is a whale and not a polliwog. The whale grows bigger and bigger, stronger and stronger, and now the mother and other adults are forced to believe the boy and his power of imagination - it is a whale after all. The story reads as an allegory of the child's right to imagine and to be free of the pressure of the society. So, the right to have an imagination turns also into the right to hope and freedom.

In their Tales for Little Rebels, Mickenberg and Nel suggest a list of additional recommended radical readings divided by the themes of each chapter. It is not accidental that chapter 5, "Imagine," gets the longest list of various wellknown books and authors, including Dr. Seuss, Pete Seeger, Maurice Sendak, and Shel Silverstein. The international additions to this list are Roald Dahl with his stories breaking all the rules, and Tove Jansson as the author of books about freedom-loving and adventurous creatures called Moomins and their friends. Dwellers of the Moominvalley are very diverse, and clearly belong to different types of creatures, if not to different species. Still, diversity is an issue that haunts children's books. Ursula Le Guin, in her talk published in 2009, notes that the characters of the American fantasy books are predominately White (pp. 4-5). Philip Nel (2017) offers a further discussion on the lack of subversive power and racial issues in American children's literature in his book Was the Cat in the Hat Black? The Hidden Racism of Children's Literature, and the Need for Diverse Books. Nel goes through the history of non-White characters in American children's books, noting how few of them exist. He also honestly states his own privileged experience: "[N]ot once in my childhood did I feel the trauma of experiencing racism - because, though it was all around me, it was never directed at me" (p. 8). Racism, probably, was also never directed at the most famous American children's authors. In his book, Nel keeps exploring the possibility for children's literature to help build an anti-racist future. I will not be going into more details on the topic of racial inequality of contemporary American children's literature; in-depth exploration of turning children's literature into something inclusive, ethnically and racially diverse, and all-encompassing without losing its subversive and artistic powers deserves a separate article. 
More on the development of radical children's literature in the United States may be found in Julia Mickenberg's (2006) Learning from the Left: Children's Literature, the Cold War, and Radical Politics in the United States. She describes the politics of publishing and progressive education in the 1920s-1960s and provides multiple examples of radical and progressive writing aimed to change the status quo of children's literature. Some books of American left-oriented writers were even able to make it to the Soviet Union during the Khrushchëv Thaw. ${ }^{4}$ One of the striking examples is the book that literally opens the doors of children's imagination. In Howard Fast's (1952) Tony and the Wonderful Door, an eleven-year old boy who lives in New York of the 1950s opens the door into the colonial past of the city and becomes friends with a Dutch boy and Native American children. The book was published in New York in 1952 and was translated and published in Moscow in 1955. As Mickenberg (2006) notes, "Tony's 'wonderful door' is a useful metaphor for understanding how and why leftists were able to play an important role in the children's book field in the mid-twentieth century" (p. 12). The book had also served as a door between Moscow and New York for the Russian readers in the 1960s and 1970s.

\section{The Soviet Experience: With the Government or Against It?}

American 1920s Left children's literature portrayed the new Soviet experiences quite favourably, and, indeed, in Soviet Russia, immediately after the Revolution of 1917, literature for young readers went into a period of particular fruition and free development. Unfortunately, it did not last long. The new Soviet Power started implementing its own understanding of art and culture. Marcuse recognized, in the words of Morton Schoolman (1984), that "philosophy and art always pose the danger that some critical meaning will escape the ideological coercion and disrupt the stability of totalitarian society" (pp. 333-334). Douglas Kellner (1984) explains Marcuse's point of view on the extreme importance of not just art and philosophy, but of literature to the Soviet state. "In Marcuse's view, the centre of opposition is shifted in the Soviet Union from philosophy to literature and art, thus the Soviet state must attempt to coerce art and cultural apparatus to serve the interest of the state. The tool for transforming art into an instrument

4 The Khrushchëv Thaw refers to a period of Nikita Khrushchëv's policies of de-Stalinization. It lasted from the early 1950s to the early 1960s. During that time, repression and censorship in the Soviet Union were significantly diminished, and millions of prisoners were released from Gulag labor camps. 
of social control is Soviet realism" (p. 215). ${ }^{5}$ Marcuse (1961) believed that "Soviet realism conforms to the pattern of a repressive state" (p. 114). Prior to the phase of the "free development of all humane faculties," Marcuse claims, "art retains its critical cognitive function: to represent the still transcendental truth, to sustain the image of freedom against a denying reality" (p. 115). Literature in general and children's literature in particular became a real battlefield where the authorities aimed to assert their understanding of culture that would serve their interests. First of all, for the new Soviet children's literature, this posed an enormous task: to get rid of most of what was written before and now was condemned as counterrevolutionary and bourgeois. The Soviet authorities very well understood that children were the future, and that by controlling the children, they will be able to control the future. They promised to provide children with a 'happy childhood,' and they defined how this childhood will be shaped. ${ }^{6}$ That is why children's literature became a state business (in a very direct sense, by closing all independent publishing houses and opening just a few giant state-controlled publishing houses for all children's literature for the entire country). The Party Congresses and the Soviet Writers' Congresses were regularly discussing ideological approaches to children's literature. As Ben Hellman (2013) states quoting the "Resolution of the $13^{\text {th }}$ Communist Party Congress":

Children's literature was taken up for discussion at the $13^{\text {th }}$ Party Congress in 1924, where a resolution, recognizing the importance of bringing forth a truly Soviet type of children's literature, was passed. What this meant was plainly stated: "We must proceed to create a children's literature under the strict control and supervision of the Party, with a view to fostering a stronger sense of class-consciousness, international solidarity and love of work" (p. 304).

Understanding the crucial role of children's literature brought the fear of its power and the desire to control it by any means necessary. First, as I mentioned, pre-revolutionary books were severely criticized and, literally, removed from the libraries. Hellman (2013) writes:

$[\mathrm{T}]$ he process of renewal was [...] much more thorough in children's literature than in writing for adults. Of the pre-revolutionary 'stock' of writers and books, as many as three quarters were effectively replaced in the 1920s. What was accepted from the old literature was mainly works that could be read as criticism of life under the Tsars (p. 297).

\footnotetext{
Soviet realism is otherwise known as Socialist realism.

6 On how happy that childhood was, see Kelly $(2008,2009)$ and Balina (2009).
} 
The new Soviet prose and poetry for children emerged very quickly, and immediately it was also scrutinised by the Party. The revolutionary movement naturally produced a new type of book that was supposed to help children embrace new socialist ideas and ideals. Together with other amazing artistic endeavours of the early 1920s, mostly in the visual arts and poetry, innovative children's literature blossomed for a few short years. The famous revolutionary poets, including Vladimir Maiakovskiı̆, were writing for children. The best avant-garde artists were illustrating children's books. But very soon the 'mighty hammer' of the Party came down upon these young and creative writers and artists in the form of the demands of Socialist realism. What did not conform to the new ideology was brutally destroyed. We will see a little bit later how similar these processes were to these that are developing right now in Putin's Russia; first, an unprecedented bloom and, almost immediately, an increasing control and attempts to introduce new censorship.

I will illustrate the situation in the young post-revolutionary Soviet State using only two cases, even though many other striking examples existed. One case is an adventure novel written by a Party apparatchik, and the other one is poetry and the life story of a non-conformist writer. Little Red Devils [Krasnye d'iavoliata], the revolutionary adventure novel by Pável Bliákhin (1923), a party member since 1903, was written during the Russian Civil War (1917-1923), and the Civil War was its major setting. The twin brother and sister, Misha and Duniasha, who want to avenge the deaths of their older brother and their father, join the Red Army to fight for the revolutionary cause against the commander of an independent anarchist army in Ukraine Néstor Makhnó and his guerrilla troops. The book's fascinating, gripping storyline and the precarious situations the young characters are in make it a page-turner. At the same time, it is full of appropriate communist, collectivist, and even internationalist ideals: one of their brothers-in-arms is a Chinese youngster Yu-yu. ${ }^{7}$ However, the freedom and independence of the main characters turned to be "too much" for the controlling authorities, and the book was criticised for the excessive red romanticism, which was a derogatory term at that time. It was also labelled as "children's avant-gardism" (Balina, 2009, p. 105), also not a favourable term. "This literary device was highly criticized by both educators and literary critics of the time, and adven-

7 In a silent movie Krasnye d'îavoliata [Little Red Devils] directed by Ivan Perestiani and Pável Bliákhin (1923), because of the complicated relationship between Soviet Russia and China, a Chinese character was replaced by a Black boy, Tom Jackson. In the later movie adaptation, Neulovimye mstiteli [The Elusive Avengers], directed by Ėdmond Keosaian (1967), the Cold War attitude transformed this character into a Romani boy Iashka. 
ture writers were accused of diminishing the significance of the victorious Red Army's achievements" (p. 105). Little Red Devils went into oblivion very soon, and the book was revived only during the Khrushchëv Thaw, when a new movie version was produced and became very popular. The Thaw was the time of new romantic aspirations, and this story again carried the 'spirit of the times.' The author luckily died a peaceful death in 1961, even though he did not write much (or rather did not publish again) until the 1950s.

An avant-garde poet Daniíl Kharms did not have such luck. He was a surrealist and absurdist poet and writer, and, together with a few other poets, he organised a poetry group named OBERIU. Without any means to survive in the early 1920s - his work would not be published for ideological reasons - he started writing for children's magazines where he implemented his innovative approaches to children's poetry. For a while, he was able to write and to publish, and his writings became quite popular. His poems were full of nonsense, puns, funny images, unexpected viewpoints, surprising storylines, and notion of child's superiority over adults. Kharms often portrays children at play, and "tries to convey the ecstasy and the rhythmic spirit of the game" (Hellman, 2013, p. 326). Speed, freedom, and wild imagination penetrated his poetry. In his poem that was called exactly "Play" (Kharms, 1930/2017), three boys transform themselves into a car, a boat, and an airplane and run as fast as possible:

Peter run down the road,
down the road,
along the pavement,
Peter run
along the pavement,
and he hollered
"Roo-roo-roo!
I am not Peter any longer!

Everybody,

move aside!

I am not Peter any longer!

I'm on wheels, I'm a car!" (p. 36).

At the end of the poem, after scaring off "a real genuine cow with some real genuine horns” (p. 39), boys are siting and resting:

"I am parked!" shouted Peter.

"I cast anchor!" shouted Vasco. 
"And I landed!" shouted Mikey.

And they sat down to rest (p. 42).

Most of Kharms's children's poems play with the absurd and the reverse roles of children and adults. "A central theme for Kharms is the disruption of order. By selecting an unusual point of view, he is able to create puzzles and miracles in the midst of everyday life" (Hellman, 2013, p. 326). That definitely contradicted the rigid Socialist realism rules, and Kharms and other Oberiuts became an easy target for Party-affiliated Soviet critics. They soon were labelled as literary hooligans and counterrevolutionaries. In 1931, Kharms and a fellow OBERIU poet, Aleksándr Vvedénskiı̌, were arrested and "accused of disrupting industrial life with their poetry. The Oberiuts were released after six months but forced to spend another six months in internal exile. [...] Vvedensky and Kharms were arrested for a second time in connection with the Nazi attack on the Soviet Union in the summer of 1941" (pp. 372, 374). Kharms was accused of spreading 'defeatist' propaganda and soon died in the prison's mental hospital in Leningrad in the beginning of the Leningrad siege. He was not the only one that met this fate. During the time of Stalin's repressions, from the end of the 1920s to 1953, dozens and dozens of children's writers and poets as well as children's books' illustrators, publishers, and editors were arrested and sentenced to prison or labour camp. Many of them were shot or died in imprisonment or soon after. Many children's writers emigrated in the first years of the Revolution. Almost the entire Samuíl Marshák's editorial team was arrested in 1937; they were accused of sabotage intended to destroy children's literature. Of course, the numbers of arrested adult writers, etc., were equally high. During just a few years in the 1930s, more than a hundred of attendees of the 1934 Writers' Congress were arrested; this number includes both adult and children's writers (p. 371). Many books were censored and taken out of the libraries and bookstores. ${ }^{8}$ The country that could 'afford' to lose so many writers and artists due to prison, death, or immigration demonstrates a very particular way of dealing with literature in general, and with children's literature especially. ${ }^{9}$

8 The detailed list of censored books may be found in Arlen Blium's (2003) volume on the history of the Soviet censorship.

9 Even in the midst of Stalin's repression, some authors were brave enough to convey a subversive message thinly disguised by the fairy tale form. During World War II, Eugeny Shvarts (1944/2019) wrote his play Drakon [The Dragon] with some clear allusions to Stalin as a dictator (Wilson, 2015). 


\section{New Russia, Old Struggles}

In Putin's Russia, children's writers are not yet arrested or killed, but one can see some frightening signs of a new governmental control over children's literature. The 2000s clearly marked the beginning of a new development in Russian children's literature. Many new authors have appeared; many interesting and innovative books for young children and for teens have been published (Bukhina, 2016). At the same time, the year 2010 marked a new campaign aiming to protect Russian children from the 'bad' influence of the 'alien' literature that does not contain the true 'Russian values.' The government authorities imposed greater restrictions on what content is appropriate for children and what is not. The bureaucrats, as always, are afraid of children's literature and try to introduce more and more laws and limitations to it. The Federal Law \#436 about "protecting children from the information harmful for their health and development" was passed. ${ }^{10}$ Still, no one really knows how to define this "harmful information." There were already a few court cases; some of them were sparked by the reactions of uninformed parents. Sometimes, it was a fear of foreign influence. The authors of a math textbook for the second grade were accused of using images from foreign fairy tales and animation movies instead of images from Russian folktales. According to the same law \#436, children's books cannot contain any "gay propaganda," which was understood as any positive mentioning of gay-related issues or introducing gay characters in the books. The anti-gay attitude was one of the main reasons for the law; this law de facto constitutes the establishing of censorship, and as a result, it pushed authors and publishers to self-censorship. In 2014, an author of the book Families: Ours and Theirs [Sem'ia u nas i u drugikh], Vera Timenchik (2008), was accused of "gay propaganda" for merely mentioning in her book families with two moms or two dads. In the same year, a second edition of another children's book, Daria Wilke's (2013/2015) Jester's Cap [Shutovskoŭ kolpak], was marked $18+$ only because it has an adult gay character portrayed positively, and it discusses the issues of gender identity and bullying by peers for the lack of

10 The federal law N-436 FZ "O zashchite deter̆ ot informatsii, prichiniaîushcheř vred ikh zdorov'iu i razvitiiu” [On Protecting Children from Information Harmful to Their Health and Development] was passed by the Russian Duma in 2010, ratified with several amendments in July 2012, and started being enforced after the next set of amendments in the July 2013; retrieved from http://www.kremlin.ru/acts/bank/32492 on January 13, 2018. The new law also requires an age rating indication $(0+, 6+, 12+, 16+$, or $18+)$ on the cover of the book. 
'masculinity.' ${ }^{11}$ These reactions are clearly coming from the fear of the Other, whoever this Other is, a person with a different sexual orientation, a different race, or an immigrant of a different origin. Timenchik's book was a part of the series of eighteen books written by different authors under the umbrella of the project on tolerance, "Other, Others, About Others," curated by a famous Russian writer Liudmila Ulitskaî. These and other similar books, originally written in Russian or translated, are striving to inform children about other cultures, languages, customs, religions, food habits, etc. ${ }^{12}$

Generally speaking, children's books tend to show diversity of the world and to fight these fears of Others. A reader of a children's book looks straight into the eyes of the Other, and he/she sees in these eyes, like in the mirror, that the Other and himself/herself are very similar, and that there is no need for confrontation. The reader, like Carroll's Alice, goes through this mirror to the other world with its sometimes-strange laws and habits. A great example of this message is a picture book by a progressive American writer Lilian Moore (1963), Little Raccoon and the Thing in the Pool, where a kid-raccoon sees his reflection in the pool and is panickily afraid of it. His mom convinces him that if he will smile at this awful creature, it will smile back and they will become friends. ${ }^{13}$ This book was translated into Russian during the Khrushchëv Thaw and became very popular, partly due to the animation movie based on it (Chúrkin, 1974). In the Russian context, the message of mutual understanding may often come precisely through translated books, and the Khrushchëv Thaw was a good time to bring this message, unlike the following period of Brezhnev's stagnation.

Perestroika ${ }^{14}$ brought a unique opportunity to publish translated books and to write original texts for children without any governmental 'supervision.' However, in the mid-2010s, the governmental attacks on children's literature

11 The scandal helped to promote the book abroad, and the publisher, Irina Balakhonova of the Samokat Publishing House, received the Jeri Laber International Freedom to Publish Award. The book was translated into English and published by Scholastics Press as Playing a Part.

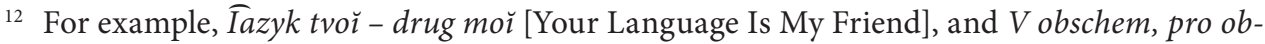
schenie [Communication Actually] by Olga Bukhina and Galina Gimon (2011, 2015; both books are the part of Ulitskaia's project), Skazhi mne, "Zdravstvuin!" [Say "Hello!" to Me] by Alekseĭ Oleĭnikov (2016), Ne/Spravedlivost' [Non/Justice] by Nika Dubrovskaîa (2017).

13 In the 1960s, Moore founded the Council on Interracial Books for Children. As it is said in her obituary by Stuart Lavietes (2004), "The council works to discover and encourage minority writers and to confront stereotypes in books for children."

${ }_{14}$ Mikhail Gorbachev's perestroika (restructuring) refers to a political movement for reformation within the Communist Party of the Soviet Union during the 1980s. 
started again, and they only intensified by the end of the decade. In January 2018, a children's ombudswoman Anna Kuznetsova (a Putin's appointee) publicly claimed that some books for children are too scary, too full of absurd, or too obscene for children to read, and they should be banned. Should kids be protected from any upsetting things in children's books? Surely, parents sometimes believe that a particular book might be too scary for their child. But how does one define 'scary'? Kuznetsova singled out sixteen books, among them several absurdist's poems (some of them were actually written in the late Soviet time) and a book based on the Komi folktales. (Komi is one of the indigenous groups in the Russian North.) In the case of the Komi book, Kuznetsova completely misunderstood its title and mistook it for something obscene. ${ }^{15}$ A group of children's writers and literary critics immediately began protesting and demanding a meeting with the ombudswoman (which was never granted), but the harm to the freedom of expression was already done. Generally, the main threat is now emerging out of a new Russian ideology of nationalism and ultra-patriotism that is trying to appropriate children's literature for its needs. It takes a form of recommendations for teachers and parents to read only Russian books with children, preferably, old Imperial or Soviet, 'time-tested,' books. Another 'approved' category is the 'kind' [dobrye] books that avoid any disturbing or difficult topics. This attitude rejects the importance of new literature as well as new translations for children and teens. Translated literature with its often more open attitude and a broader scope of ideas was always one of the strongest features of children's reading in Russia, but more detailed analysis of the subversive potential of translated books in the Russian and international context is beyond of the scope of this article. The debates around what is good and what is bad for children to read are heavily mixed with this patriotic ideology and attached to the national idea that aims to 'protect' children from the subversive influence of imaginative, diverse, and 'foreign' books. It is a political issue that reflects the condition of the society as a whole. The nationalist and anti-gay voices are very strong, but children's writers and publishers are fighting back, both in the form of producing new books and in political activism.

15 Meduza, 2018. This situation, unfortunately, did not get enough attention from Western journalists. 


\section{Conclusion: A Hope}

To the shock and the annoyance of such adults as the ombudswoman Anna Kuznetsova and to the love and the admiration of children, many children's books' authors are expanding the border of norms and habitual views. The subversive power of children's literature manifests itself in all texts that question the established order and stale moral and social principles. This explosive ability of children's books did contribute to the changes in people's consciousness during the last two centuries (which is the period in history with the fastest technological, political, and cultural changes). In any case, the birth of modernity, the birth of children's literature, and the drastic change in the speed of historical development came together, hand in hand. At the same time, this ability to destroy the borders and walls often caused children's books and their authors much trouble. Nevertheless, what was censored and banned, like Daniíl Kharms's poetry, now, ninety years later, is considered classics and is included in school programs in Russia. Unfortunately, the censorship of children's literature is still practiced in some forms and in many countries; this is, alas, not only a Russian problem. In France, for example, the authorities recently did not like that some children's books 'teach' children how to disobey by showing the adults in funny and undignified situations. After the attempt of some officials to criticise one picture book mentioning (and portraying) adult nudity, French booksellers posed naked and issued the following statement: "Naked to support those works which open imaginations, widen horizons and debates. The book should not be the target of intolerance - it allows all citizens the possibility of having an informed look at today's society, and the world of tomorrow" (Flood, 2014). The same goes for the scary content of children's books. The desire to protect children from unpleasant and frightening experiences is natural. Still, these books are absolutely necessary for children's development, as eloquently expressed by the American writer Lois Lowry, the author of a famous 1992 young readers' dystopia The Giver: "I had kids and I have grandchildren, and I would like to protect them from everything in the world. But in honesty I do think that literature is a way that kids can explore what they're going to have to face when they're older, and they can do it safely" (Anderson, 2013). Children tend to identify themselves with the brave and adventurous heroes, even if these characters are in grave danger in the book. As Alison Lurie (1998, p. 95) notes discussing one of the oldest adventure picture books for very small children, Beatrice Potter's (1902) The Tale of Peter Rabbit, "disobedience and exploration are more fun than good behavior, and not really all that dangerous, whatever Mother may say". 
The carnivalesque qualities of children's books, the grotesque body, and the connections to the bodily lower stratum help children to gain more freedom and to push borders even further. Maria Nikolajeva (2010/2012) suggests that "carnival empowers child protagonists and give them self-confidence necessary to cope with problems after the time-out of the carnival is over" (p. 150), but she points out that the carnival often is only a temporary state of empowerment, and it makes children only "slightly more powerful than their environment" (p. 42). Nevertheless, the subversiveness and empowerment hidden in children's books may provide a child (and later a grown-up) with an ability and desire to protest and fight against all sorts of oppression and injustice. The reader (a child or an adult) may fly with Peter Pan to the Never-Never Land of absolute freedom or travel by boat with Max to the Wild Things' island of absolute power. This experience may later lead to a development of the spirit of defiance. Unfortunately, the effect of children's books and youth radicalism tends to wear out with age, and this, again and again, breeds generations of conservative adults. But as much as some of them may be afraid of children's and children's writers' imagination, they will never be able to stop it. As a French writer Timothée de Fombelle expressed it: "I am very optimistic. The book for children gradually transforms itself into the tool of distinctive resistance - to the authority of adults, parents, and teachers" (Labirint.ru, n.d.). ${ }^{16}$

\section{References}

Anderson, K. (2013, January 4). Interview with Lois Lowry. Studio 360 (PRI). Retrieved from https://www.wnycstudios.org/podcasts/studio/episodes/260152-loislowry-romare-bearden.

Balina, M. (2009). “It is grand to be an orphan!". In M. Balina \& E. Dobrenko (Eds.), Petrified utopia: Happiness Soviet style (pp. 99-114). London \& New York, NY: Anthem Press.

Blium, A. V. (2003). Zapreshchennye knigi russkikh pisatele $̌$ i literaturovedov. 1917-1991. Indeks sovetskoŭ tsenzury s kommentariiami. St. Petersburg: SPb GUKI.

Bliâkhin, P. (1923). Krasnye d'iavoliata (Okhota za goluboŭ lisițsĕ). Baku: Bakinskiı̌ rabochiı̌.

16 Timothée de Fombelle $(2010,2011)$ is the author of two of the most powerful contemporary adventure books, Entre ciel et terre [Vango: Between Sky and Earth] and Un prince sans royaume [A Prince without Kingdom]. 
Boland, M. (2008). ABC for Martin. In J. Mickenberg \& P. Nel (Eds.), Tales for little rebels: A collection of radical children's literature (J. Zipes, Foreword, pp. 19-21). New York, NY: New York University Press. (Original work published 1935).

Bould, M., \& Vint, S. (2012). Political readings. In E. James \& F. Mendlesohn (Eds.), The Cambridge companion to fantasy literature (pp. 102-112). Cambridge: Cambridge University Press.

Bowers, M. A. (2004). Magic(al) realism (The new critical idiom). New York, NY \& London: Routledge.

Bukhina, O. (2016). Reports of its death are greatly exaggerated: The making of contemporary Russian children's literature (K. Cargill, Trans.). Russian Studies in Literature, 52(2), 103-113. https://doi.org/10.1080/10611975.2016.1243368.

Bukhina, O., \& Gimon, G. (2015). Tazyk tvŏ - drug mol̆. Moskva: Eksmo.

Bukhina, O., \& Gimon, G. (2015). V obschem, pro obschenie. Moskva: Eksmo.

Carroll, L. (1865). Alice's adventures in Wonderland. London: Macmillan.

Chúrkin, O. (Director). (1974). Kroshka Enot [The little coon] [Motion picture]. Soviet Union: Tvorcheskoe ob"edinenie "Ėkran."

Collins, S. (2008). The Hunger Games. New York, NY: Scholastic.

Collins, S. (2009). Catching fire. New York, NY: Scholastic.

Collins, S. (2010). Mockingjay. New York, NY: Scholastic.

Dr. Seuss (1989). And to think that I saw it on Mulberry street. New York, NY: Random House Books for Young Readers. (Original work published 1937).

Dubrovskaia, N. (2017). Ne/Spravedlivost'. Moskva: Samokat.

Ende, M. (1993). The neverending story (R. Manheim, Trans.). London: Puffin Books. (Original work published 1979).

Fast, H. (1952). Tony and the wonderful door. New York, NY: The Blue Heron Press.

Flieger, V., \& Anderson, D. A. (Eds.). (2008). Tolkien on fairy-stories. New York, NY: HarperCollins.

Flood, A. (2014, February 26). French booksellers pose naked to support children's book on nudity. The Guardian. Retrieved from https:/www.theguardian.com/ books/2014/feb/26/french-booksellers-pose-naked-childrens-book-nudity-tous-apoil.

Fombelle de, T. (2016a). Vango: Between sky and earth (S. Ardizzone, Trans.). New York, NY: Candlewick. (Original work published 2010).

Fombelle de, T. (2016b). A Prince without kingdom (S. Ardizzone, Trans.). New York, NY: Candlewick. (Original work published 2011).

Gibson, L. (2008). The teacup whale. In J. Mickenberg \& P. Nel (Eds.), Tales for little rebels: A collection of radical children's literature (J.Zipes, Foreword, pp. 151-156). New York, NY: New York University Press. (Original work published 1934).

Gold, L. (2008). X: A fabulous child's story. In J. Mickenberg \& P. Nel (Eds.), Tales for little rebels: A collection of radical children's literature (J. Zipes, Foreword, 
pp. 233-242). New York, NY: New York University Press. (Original work published 1979).

Handy, B. (2017). Wild Things: The joy of reading children's literature as an adult. New York, NY: Simon \& Schuster.

Hellman, B. (2013). Fairy tales and true stories: The history of Russian literature for children and young people (1574-2010). Leiden \& Boston, MA: Brill.

Jackson, R. (2003). Fantasy: The literature of subversion. London: Routledge.

James, E., \& Mendlesohn, F. (Eds.). (2012). The Cambridge companion to fantasy literature. Cambridge: Cambridge University Press.

Kellner, D. (1984). Herbert Marcuse and the crisis of Marxism. Berkeley, CA \& Los Angeles, CA: University of California Press.

Kelly, C. (2008). Children's world: Growing up in Russia, 1890-1991. New Haven, CT: Yale University Press.

Kelly, C. (2009). A joyful Soviet childhood: Licensed happiness for little ones. In M. Balina \& E. Dobrenko (Eds.), Petrified utopia: Happiness Soviet style (pp. 3-18). London \& New York, NY: Anthem Press.

Kharms, D. (2009). Today I wrote nothing: The selected writings of Daniil Kharms (M. Yankelevich, Trans.). New York, NY: The Overlook Press.

Keosaian, E. (Director). (1967). Neulovimye mstiteli [Motion picture]. Soviet Union: Mosfilm.

Kharms, D. (2017). Play. In V. Mayakovsky, O. Mandelstam, \& D. Kharms, The fire horse: Children's poems by Vladimir Mayakovsky, Osip Mandelstam and Daniil Kharms (E. Ostashevsky, Trans., pp. 36-42). New York, NY: NYR Children's Collection.

Kuznetsov, S. (2011). Zhivye i vzroslye. Moskva: Astrel.

Labirint.ru. (n.d.). Kruglyı̆ stol. Kakoĭ budet detskaîa literatura cherez desiat' let? Retrieved from https://www.labirint.ru/child-now/buduschee-detskoy-literatury/.

Lavietes, S. (2004, August 2). Lilian Moore, 95, who wrote books for children, is dead. Retrieved from http://www.nytimes.com/2004/08/02/books/lilian-moore95-who-wrote-books-for-children-is-dead.html.

Le Guin, U. K. (2009). Cheek by jowl: Talks and essays on how and why fantasy matters. Seattle, WA: Aqueduct Press.

Lowry, L. (1992). The Giver. New York, NY: Houghton Mifflin.

Lurie, A. (1998). Don't tell the grown-ups: The subversive power of children's literature. Boston, MA, New York, NY, Toronto, \& London: Back Bay Book.

Marcuse, H. (1961). Soviet Marxism: A critical analysis. New York, NY: Vintage Books. Marcuse, H. (1969). An essay on liberation. Boston, MA: Beacon Press.

Mayakovsky, V., Mandelstam, O., \& Kharms, D. (2017). The fire horse: Children's poems by Vladimir Mayakovsky, Osip Mandelstam and Daniil Kharms (E. Ostashevsky, Trans.). New York, NY: NYR Children's Collection. 
Meduza (2018, February 2). Ombudsmen nashla 16 "detskikh" knig, kotorye "dazhe vzroslym pokazyvat' nel'zia." Ona oshiblas': v spiske okazalis' klassika i fol'klor. Retrieved from https://meduza.io/feature/2018/02/02/ombudsmen-nashla-16detskih-knig-kotorye-dazhe-vzroslym-pokazyvat-nelzya-ona-oshiblas-v-spiskeokazalis-klassika-i-folklor.

Mickenberg, J. (2006). Learning from the left: Children's literature, the Cold War, and radical politics in the United States. New York, NY: Oxford University Press.

Mickenberg, J., \& Nel, P. (Eds.). (2008). Tales for little rebels: A collection of radical children's literature (J. Zipes, foreword). New York, NY: New York University Press.

Moore, L. (1963). Little raccoon and the thing in the pool. Greensboro, NC: Carson-Dellosa Publishing.

Mourlevat, J.-C. (2009). Winter's end (A. Bell, Trans.). New York, NY: Candlewick. (Original work published 2006).

Nel, P. (2017). Was the Cat in the Hat Black? The hidden racism of children's literature, and the need for diverse books. Oxford: Oxford University Press.

Nikolajeva, M. (2012). Power, voice and subjectivity in literature for young readers. New York, NY \& London: Routledge. (Original work published 2010).

Oleŭnikov, A. (2016) Skazhi mne, "Zdravstvuil!". Moskva: Samokat.

Ostashevsky, E. (2006). OBERIU: An anthology of Russian absurdism. Evanston, IL: Northwestern University Press.

Perestiani, I., \& Bliákhin, P. (Directors). (1923). Krasnye d'îavoliata [Red devils] [Motion picture]. Soviet Union: Cinema section of People's Commissariat of Georgia \& Odessa Film Studio.

Potter, B. (1902). The tale of Peter Rabbit. London: Frederick Warne.

Rosoff, M. (2006). How I live now. Toronto: Wendy Lamb Books.

Rowling, J. K. (1997). Harry Potter and the Sorcerer's Stone. London: Bloomsbury.

Rowling, J. K. (1998). Harry Potter and the Chamber of Secrets. London: Bloomsbury.

Rowling, J. K. (1999). Harry Potter and the prisoner of Azkaban. London: Bloomsbury.

Rowling, J. K. (2000). Harry Potter and the Goblet of Fire. London: Bloomsbury.

Rowling, J. K. (2003). Harry Potter and the Order of the Phoenix. London: Bloomsbury.

Rowling, J. K. (2005). Harry Potter and the Half-Blood Prince. London: Bloomsbury.

Rowling, J. K. (2007). Harry Potter and the Deathly Hallows. London: Bloomsbury.

Salminen, J. (2009). Fantastic in form, ambiguous in content: Secondary worlds in Soviet children's fantasy fiction. Turku: Turun Yliopisto.

Saul, O. (2008). Revolt of the beavers. In J. Mickenberg \& P. Nel (Eds.), Tales for little rebels: A collection of radical children's literature (J. Zipes, Foreword, pp. 110-116). New York, NY: New York University Press. (Original work published 1936). 
Saunders, R. J. (1962). The ethics of the imagination. Art Education, 15, 6, 12-14.

Schoolman, M. (1984). The imaginary witness: The critical theory of Herbert Marcuse. London: Collier Macmillian Publishers.

Shvarts, E. (2019). The dragon (L. Senelick, Trans.). New York, NY: Broadway Play Publishing. (Original work published 1944).

Timenchik, V. (2008). Sem'ia u nas i u drugich. Moskva: Eksmo.

Wilke D. (2015). Playing a part (M. Schwartz, Trans.). New York: Arthur A. Levine Books. (Original work published 2013).

Williams, J. (2008). The practical princess. In J. Mickenberg \& P. Nel (Eds.), Tales for little rebels: A collection of radical children's literature (J. Zipes, Foreword, pp. 161-167). New York, NY: New York University Press. (Original work published 1969).

Wilson, S. (2015). Fairy tale or subversion? Evgeny Shvarts's The Dragon as anti-Stalinist theatre for youth. Theatre Symposium, 23, 52-66. https://doi.org/10.1353/ tsy.2015.0005. 